\title{
O papel da história na construção da teoria política de Maquiavel
}

Fábio Coimbra

\section{Resumo:}

O propósito desta pesquisa consiste em fazer uma análise de como a história é tematizada, bem como examinar a sua relevância na construção da teoria política de Maquiavel, uma vez que ele sempre retorna a ela para falar da ação política. Perceber-se-á que essa tematização constitui-se precisamente como uma estratégia fundamental para a ação política dos príncipes, haja vista serem esses os destinatários das lições políticas do florentino. Daí ser necessário e, portanto, relevante que os príncipes sejam bons conhecedores da história, sobretudo das histórias dos grandes homens, aqueles que alcançaram êxito em suas empreitadas, tanto para a aquisição do poder, como para nele permanecer. Palavras-chaves: Nicolau Maquiavel - História - estratégia - ação política 


\section{Introdução}

O trabalho em questão discorre sobre o papel da história na construção da teoria política de Maquiavel. O objetivo aqui consiste em elucidar como a história se torna relevante no cerne do pensamento político desse autor. Como depositária de todos os acontecimentos, dentre os quais se destacam aqui os acontecimentos políticos, Maquiavel aconselha o príncipe a ler as histórias, especificamente as histórias dos grandes homens. A finalidade disso seria a imitação - por parte dos príncipes - daquelas ações que foram vitoriosas. Para isso, seria necessário que o príncipe enfatizasse, no estudo da história, especificamente as causas das vitorias e das derrotas e as estratégias que foram usadas para isso. E a partir daí, procurar imitar as ações vitoriosas e abandonar as que não tiveram êxito.

Quanto à estrutura, o trabalho está dividido em duas partes. Na primeira, intitulada "A história como mestra", buscar-se-á demonstrar que a história é mestra dos homens, dado que eles aprendem a partir da observação das experiências do passado. E, como tal, é justamente dela (a história) que Maquiavel se vale para a construção de sua teoria política. Examinar-se-á também, nessa primeira parte, como se dá o rompimento de Maquiavel com a tradição político-filosófica que tinha em Platão e Aristóteles sua autoridade máxima. O ponto de partida de Maquiavel nessa desconstrução da tradição é a introdução da noção de "verdade efetiva das coisas", que consiste em tomar a vida da maneira como ela é vivida e não como deveria ser - já numa contraposição direta a Platão. A segunda parte, à sua vez, intitulada "A história como meio", discorrerá sobre em que sentido a história pode ser concebida como meio no coração da nova teoria política que surge com Maquiavel e que pretende ser diferente das teorias precedentes. A hipótese aqui levantada é a de que, enquanto meio, a história se traduz em ponte que conduz do passado ao presente e, reciprocamente, deste àquele. Do passado, ela traz os acontecimentos para que os homens do presente os examinem, dados os fins a que pretendem alcançar. Do presente, ela conduz os homens ao passado na medida em que para atingir certos objetivos eles precisam observar como agiram alguns homens que foram vitoriosos antes deles. Em suma, a pesquisa se esforçará para ilustrar como a finalidade do retorno que Maquiavel faz à história consiste em analisar como os homens se comportaram e agiram em determinadas circunstâncias de modo a conciliar seus objetivos com os acontecimentos próprios de suas épocas. 


\section{A história como mestra}

A temática da história como mestra no cerne da filosofia política de Maquiavel, indubitavelmente, é de uma magnitude fundamental para a compreensão das lições que, a partir dela, ele pretendera dar aos príncipes, ou ao príncipe (leia-se: Lourenço de Medici).

Em sendo artífice de uma nova teoria política - que pretendera ser diferente de todas as outras que a precedera -, Maquiavel se vale da história para essa laboriosa construção. Para um entendimento adequado dessa nova teoria que está sendo proposta, cabe ressaltar aqui - dentre tantas outras - duas das preocupações fundamentais de Maquiavel que consistem em, primeiro, compreender as razões pelas quais os homens são levados a agir de determinada forma em determinadas circunstâncias (o que equivale ao que ele chamara de verita efetuale de la cosa, ou seja, "verdade efetiva das coisas") e, segundo, conferir à política a autonomia que lhe é devida. Cumpre precisar que é a partir da noção de verdade efetiva das coisas - que nada mais é senão os acontecimentos concretos de uma realidade vivida - que Maquiavel caminha no sentido de tornar a política uma ciência autônoma. Nesse sentido, tornar a política uma ciência autônoma consiste nada mais nada menos que numa distinção entre aquilo que é próprio dela e aquilo que não o é, e, consequentemente, promover a sua independência a partir daí. Sendo assim, o primeiro esforço de Maquiavel será dirigido no sentido de ir de encontro com uma tradição secular ancorada, sobretudo, em Platão e Aristóteles. Essa empreitada de Maquiavel contra a tradição se expressa com maior clareza no capítulo XV de $O$ príncipe, no qual ele refere a máxima que norteia a construção da sua teoria, conforme se lê:

[...] sendo meu intento escrever algo útil para quem me ler, parece-me mais conveniente procurar a verdade efetiva das coisas do que uma imaginação sobre ela. [e tecendo uma crítica direta a Platão, diz] Muitos imaginaram repúblicas e principados que jamais foram vistos e que nem se soube se existiram na verdade, porque há tamanha distância entre como se vive e como se deveria viver, que aquele que trocar o que se faz por aquilo que se deveria fazer aprende antes sua ruína do que sua preservação; pois um homem que queira fazer em todas as coisas profissão de bondade deve arruinar-se entre tantos que não são bons. Daí ser necessário a um príncipe, se quiser manter-se, aprender a poder não ser bom e a se valer ou não disso segundo a necessidade (MAQUIAVEL, I996, p. 73).

Essa passagem possui uma relevância magnífica para a compreensão da teoria política de Maquiavel dado que nela está contida a fórmula maquiaveliana que 
marca definitivamente o rompimento desse filósofo com a tradição do pensamento político antigo e medieval. E a fórmula é a verdade efetiva das coisas, a qual consiste em tomar as coisas, ou ainda, considerá-las a partir do que elas são, tal como se nos apresentam e se nos aparecem.

Com a noção de "verdade efetiva", Maquiavel mostra sua contraposição em relação àqueles que se ocupavam de assuntos políticos, no entanto, considerando as coisas a partir daquilo que elas deveriam ser, como Platão com o seu mundo das ideias. Sendo assim, Maquiavel critica esse filósofo mostrando que a preocupação com aquilo que deveria ser - em vez de ser como aquilo que é - nada mais seria do que uma contribuição para a ruína de quem assim procedesse. Com essa reflexão, Maquiavel insinua que o príncipe deve ser profundo observador da vida humana. Deve também, observar as ações dos homens, seus comportamentos e outras coisas conforme se pode ver também em outras partes da obra, por exemplo, no capítulo XVIII, no qual ele compara o príncipe a um centauro e exemplifica fazendo uma referência aos antigos que, segundo ele, "escreveram que Aquiles e muitos outros príncipes antigos haviam sidos criados por Quíron, o centauro que os guardara sob sua disciplina"(ibidem, p. 83). E é precisamente nesse sentido que a história se torna mestra dos homens, sobretudo daqueles que pretendem alcançar a vitória. Como mestra, a história mostra aos homens de um tempo presente os grandes feitos dos homens do passado. Obviamente, são as ações vitoriosas que mais devem interessar para os príncipes, que visam sucesso em seus empreendimentos. É nesse sentido, portanto, que Maquiavel fixa a história como mestra ao dizer no capítulo XIV o que se segue:

[...] deve o príncipe ler as histórias e refletir sobre as ações dos homens excelentes, ver como se comportaram nas guerras, examinar as causas das vitórias e derrotas, afim de poder escapar destas e imitar aquelas. Mas, sobretudo, deve agir como agiram antes alguns homens excelentes que se espelharam no exemplo de outros que, antes deles, haviam sido louvados e glorificados e cujos gestos e ações procuram ter sempre em mente [...] (ibidem, p. 7I).

Aqui fica claro, portanto, a importância da história e a posição que ela ocupa (leia-se: o privilégio) no seio da teoria política de Maquiavel. E é recorrendo sempre à história que o filósofo inaugura uma nova forma de se pensar a política. Cumpre ressaltar que não é com um intuito de erigir modelos de ação ou conduta que Maquiavel faz um retorno eterno à história, mas sim com o intuito de falar da ação política. Se é possível falar em um modelo de ação em Maquiavel, esse modelo só pode ser a própria história 
repleta de acontecimentos, mas jamais um homem em particular por mais que tenha sido vitorioso. Pois os homens sempre mudam tanto interna-em se tratando da palavra que pode facilmente ser quebrada - quanto externamente - tratando-se aqui das influências que os homens sofrem do meio no qual habitam e que podem interferir no curso de suas ações. O que se deve, portanto, levar em conta ao se considerar os acontecimentos históricos pelos quais muitos homens foram louvados é, sobretudo, o conjunto das ações que tomaram para saírem vitoriosos. Também sobre a história como mestra e máxima de ação Maquiavel refere

Ouvir dizer que a história é a mestra das nossas ações e máxima dos príncipes: e o mundo foi sempre, de certo modo, habitado por homens que têm tido sempre as mesmas paixões; e sempre existiu quem serve e quem manda, e quem serve de má vontade e quem serve de bom grado, e quem se rebela e quem se rende (MAQUIAVEL apud AQUINO, 2006, p. 67).

Nessa perspectiva - através do conhecimento da história, considerando que, em algum aspecto, há certa constância das coisas humanas (o que é fundamental para a ideia de caráter pedagógico da história) - pode-se argumentar que a história permite formular máximas sobre o comportamento humano. Como tal, é ela que ensina aos homens como eles devem agir em determinadas circunstâncias. Sendo o conhecimento da história uma estratégia de ação na política teorizada por Maquiavel, ela (história) se tornara por excelência a base das lições que ele pretendera dar aos príncipes. Em suma, a história é uma verdadeira mestra, dado que com ela se aprende a partir da observação das ações dos grandes homens.

\section{A história como meio}

Reconhecer a história como um meio pelo qual as ações do presente são previamente espelhadas em algumas das do passado - ressaltando-se aquelas que foram dignas de glória e que foram próprias dos grandes homens - significa reconhecê-la, portanto, como uma espécie de ponte que faz a ligação entre o passado e o presente e, reciprocamente, entre o presente e o passado. Em sendo uma ponte, é ela que faz a condução dos grandes acontecimentos de uma época a outra. Poder-se-ia dizer também que a história é a grande memória do mundo, na qual tudo se armazena. Ainda poderia se argumentar, em suma, que ela é como que a caixa preta do mundo, que registra e contém em si todos 
os dados, todas as informações, todos os acontecimentos, de modo que tudo o que se sabe sobre ela ainda é muito pouco diante de sua amplitude e vastidão.

Para ilustrar melhor a hipótese da história enquanto meio, da maneira como foi descrita acima, cumpre retomar aqui a questão da verdade efetiva. Como exemplo da verdade efetiva pode-se tomar o próprio contexto político no qual vivera Maquiavel: um território todo fragmentado em estados independes e desarmônicos. São exemplos: a República de Veneza, os Estados Pontifícios, o Ducado de Milão, o Reino de Nápoles e a República de Florença. No tempo de Maquiavel, era essa uma das verdades efetivas e é a partir dela que o florentino formula seu pensamento político, o que ajuda a compreender melhor a configuração da história como meio.

Se no contexto da Idade Média - em uma analogia - o homem estava voltado para as coisas do céu (leia-se: as preocupações e afazeres da vida religiosa, dando mais atenção para certas coisas abstratas), Maquiavel puxa-lhe para baixo, para mostrar-lhe que é na terra que ele vive, no contexto de uma realidade problemática, complexa e difícil. A complexidade dessa realidade se deve, sobretudo, ao fato de que o homem muda a todo instante, de modo que não se pode esperar dele ser amanhã aquilo que demonstrara ser hoje. Portanto, a preocupação política de Maquiavel é com o presente, com a realidade concreta tal qual é vivida, a verdade efetiva, o modo como ela se apresenta, aquilo que ela, de fato, é.

Tomando os homens tais como são, um dos elementos imprescindíveis para o sucesso do príncipe passa a ser a força. A relevância desta é de magnitude tal que Maquiavel dedica toda a primeira parte de sua obra-prima ( $O$ príncipe) para refletir sobre ela. Tradicionalmente pensava-se que para governar era preciso ter força. Daí a ideia de que o príncipe tinha que ter um poderoso exército. Desse modo, a ideia de que o poder político se constitui como uma força aparece como central na primeira parte de $O$ príncipe. Entretanto, mais importante que a força é a inteligência no seu uso. Ou seja, é preciso que o príncipe também seja inteligente. Pois, de acordo com o florentino, "há dois gêneros de combate: um com as leis [leia-se: a inteligência] e outro com a força. O primeiro é próprio ao homem, e o segundo é o dos animais." (MAQUIAVEL, I996, p. 83). Desse modo, ele chama a atenção para aquilo que vai aparecer no capítulo XVIII, quando compara o príncipe a um centauro, para dizer que ele compartilha uma natureza que é dupla. "Assim, o príncipe deve saber usar as qualidades próprias de dois animais, por um lado a ferocidade e a força do leão, e por outro lado, a astúcia da raposa, a capacidade de dissimular, a habilidade de enganar os outros."(LIMONGI, 2006, p. 28). Deve, então, o príncipe se comportar ora como humano, ora como animal, 
mas somente (e somente se) quando assim for necessário. Ao insinuar que o príncipe deve aprender a não ser bom, Maquiavel não quer dizer que com isso ele deverá ser sempre mal. Em outras palavras, significa dizer que o filósofo não está legitimando as ações más do príncipe, mas apenas advertindo-o a ficar atento e guiar sua conduta de acordo com o desenvolvimento dos acontecimentos, tomando como exemplo sempre os feitos históricos dos homens que alcançaram a vitória naquilo que fizeram e que a história, como meio, logrou disponibilizar-lhe. Sendo assim, ele refere que quem quiser ser somente bom vai se arruinar em meio a tantos que não são bons, logo o príncipe deve aprender a usar a maldade para ferir quando isso se mostrar como uma necessidade de fato. A força é, portanto, um elemento necessário na vida política, especialmente porque é por meio dela que se pode assegurar a paz, o progresso e a permanência do príncipe no poder.

É evidente que o pensamento de Maquiavel é um reflexo das observações que ele fazia a respeito da ação dos príncipes, tanto os de seu tempo - os quais ele pôde observar nas muitas viagens que fizera com secretário de Florença - quanto os príncipes antigos que se constituem como exemplos clássicos, dentre os quais podem se destacar "Lívio, Políbio, Tucídides e Xenofonte" (ibidem, p. 25). Em suma, o que Maquiavel quer com a história não é buscar nela determinadas regras de ação, mas sim analisar como se deu, ou como se dá, a relação entre a ação e as circunstâncias. Em outras palavras, significa dizer que o retorno à história empreendido por Maquiavel visa especificamente compreender a relação entre a fortuna e a virtù. Ou seja, como os homens vitoriosos foram capazes de conciliar os fins a que pretendiam alcançar com o desdobramento simultâneo dos acontecimentos próprios de suas épocas.

\section{Iv. Considerações finais}

Ao discorrer sobre a relevância da história na elaboração do pensamento político de Maquiavel, a pesquisa teve como intenção elucidar como e de que forma, neste filósofo, a história se torna mestra dos homens e meio pelo qual eles podem chegar ao alcance dos objetivos que perseguem.

Entendendo a história como a memória do mundo, uma vez que nela se armazenam todos os tipos de experiências e acontecimentos vividos pelos homens nos Estados, a pesquisa buscou examinar as razões pelas quais Maquiavel aconselha os príncipes a serem leitores ou estudiosos da história, dado que com ela se aprende. E foi justamente nessa perspectiva que se tratou de mostrar a história como mestra das ações humanas. 
Num segundo momento, discorrendo sobre a história como meio, buscou-se mostrar e esclarecer como e em que sentido ela pode ser concebida como uma espécie de ligação entre o presente e o passado. Esclareceu-se também como, em Maquiavel, se deu o processo de obtenção da autonomia da política. Nesse sentido, foi mostrado que o primeiro passo dado pelo florentino rumo a isso foi contrapor-se às teorias político-filosóficas antigas e medievais, visando assim a uma desconstrução de uma tradição secular que tinha como sustentáculo o pensamento de Platão e Aristóteles. O ponto de partida de Maquiavel, tal como fora colocado pela pesquisa, consistiu em considerar a realidade tal qual é, do jeito como ela se apresenta, e não como deveria ser. Viver como se deveria viver e não como, de fato, se vive é uma excelente maneira do homem (leia-se: os príncipes) se arruinar. Daí a razão pela qual Maquiavel, na construção da sua teoria, considera os homens a partir daquilo que eles são e não daquilo que deveriam ser. Mestra e meio, a história sempre mostra aos homens os grandes feitos dos homens do passado. E, se não lhes determina (aos homens do presente) a ação, dado que os homens mudam, ao menos lhes indica a maneira mais prudente de como devem fazer para alcançar suas metas a partir dos registros do passado.

\section{Referências bibliográficas}

AQUINO, João Emiliano Fortaleza de. Memória e consciência histórica. Fortaleza: EdUEGE, 2006. (coleção Argentum Nostrum).

LIMONGI, Maria Isabel. O príncipe. In: Discutindo textos filosóficos. Curitiba: SESG-PR, 2006.

LOPES, Marcos Antônio. Antimaquiavelismo. In: Filosofia, São Paulo, n. 23, ano II, p. 34-4I.

MAQUIAVEL, Nicolau. O príncipe. Trad. Maria Júlia Goldwasser. 2. ed. São Paulo: Martins Fontes, I996. (coleção Clássicos).

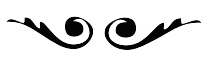

Fábio Coimbra - Mestrando em Cultura e Sociedade pela Universidade Federal do Maranhão. antaresf84@yahoo.com.br 